\title{
UNSETTLING THE GEOGRAPHY OF OAKLAND'S WAR ON POVERTY
}

\section{Mexican American Political Organizations and the Decoupling of Poverty and Blackness ${ }^{1}$}

\author{
Juan C. Herrera \\ Department of Ethnic Studies, University of California, Berkeley
}

\begin{abstract}
Historical studies of the War on Poverty have overwhelmingly focused on its consequences in African American communities. Many studies have grappled with how War on Poverty innovations co-opted a thriving African American social movement. This paper explores the impact of War on Poverty programs on the development of a political cadre of Mexican American grassroots leaders in Oakland, California. It investigates how coordinated 1960s protests by Mexican American organizations reveal Oakland's changing racial/ethnic conditions and shifting trends in the state's relationship to the urban poor. It demonstrates how a national shift to place-based solutions to poverty devolved the "problem of poverty" from the national to the local level and empowered a new set of actors-community-based organizations-in the fight against poverty. This essay argues that the devolution of federal responsibility for welfare provided the political and institutional opening for the rise of powerful Mexican American organizations whose goal was the recognition of a "Mexican American community" meriting government intervention. This essay also demonstrates how Mexican American organizations mobilized in relation to African American social movements and to geographies of poverty that were deemed exclusively Black.
\end{abstract}

Keywords: Mexican Americans, Social Movements, Community-Based Organizations, Devolution, Poverty

\section{INTRODUCTION}

On April 15 1966, Oakland's Mexican American Unity Council held a press conference to announce a six-point list of demands from city hall. The manifesto boldly called on the newly elected Republican mayor, John R. Reading, to appoint a Mexican American to the city council. The Oakland Tribune (1966) reported that the group also sought the hiring of an expert who could "train the city council and other civic leaders" to better recognize the problems of the Spanish-speaking ${ }^{2}$ community 
(p. 4). Activists delivered their manifesto in a language of urgency with a fierce determination to be heard by city officials and Oakland residents. Collectively, these requests endeavored to secure equal funding for Spanish-speaking residents in Oakland's War on Poverty. Mexican American leaders were concerned that such funding would be directed predominantly toward alleviating African American disadvantage, leaving the Spanish-speaking community with little monies. Activists argued "Oakland, whose motto is 'The All-American City' should be for all Americans: that the Treaty of Guadalupe ${ }^{3}$ should be honored to the letter as well as in spirit" (Oakland Tribune 1966, p. 4).

This essay investigates how coordinated 1960s protests by Mexican American political organizations reveal Oakland's changing racial/ethnic conditions and shifting trends in the state's relationship to the urban poor. It charts the increasing role of community-based advocacy and service provision during a period commonly understood as the apex of federally directed welfare programs. It demonstrates how a national shift to place-based solutions to poverty devolved the "problem of poverty" from the national to the local level and empowered new actors such as nonprofit organizations in the fight against poverty (Marwell 2004; O'Connor 1996, 1999). Focused on Mexican American organizations, this essay also examines how these groups demanded antipoverty funding by challenging the conflation of racial inequality and poverty with African American disadvantage. This coupling of poverty and Blackness was in part constructed by an impressive list of poverty studies that focused on urban ghettoes and "rendered technical" 4 the needs, desires, and behaviors of the poor. The focus of the War on Poverty as a solution to African American disadvantage also reflected White middle-class fears about the "threat" of Black radicalism and violence.

Fearing a repeat of the Watts riots that had taken place in Los Angeles in 1965, President Lyndon Johnson's administration targeted Oakland in the War on Poverty in 1965 . By 1968, 140 nonmilitary federal programs were spending close to $\$ 100$ million a year in Oakland, an amount dwarfing the city's own budget of \$57.9 million (Orozco et al., 2008; Pressman 1975; Self 2003). Designed to eradicate poverty, federal legislation between 1964 and 1971 provided generous funding for antipoverty programs that included job, educational, and social service projects—all focused on a new agenda of human development rather than improving decaying urban structures or eliminating structural inequalities (Katz 1993; Self 2003; Weir 1988). The War on Poverty was fundamentally concerned with the "empowerment" of the poor-a term that signaled a new understanding of poverty and how to fight it (Cruikshank 1999). Antipoverty experts introduced programmatic innovations such as Head Start, remedial instruction, elementary summer school, and neighborhood legal services to improve the quality of life in America's ghettoes. The federal government's antipoverty agenda relied on empowering local communities to develop, organize, and implement federally funded antipoverty programs and slowly to devolve control for these to local communities (Kramer 1969; Marris and Rein, 1967; O'Connor 1996).

Historical studies of the War on Poverty have overwhelmingly focused on its consequences in African Americans communities and social movements (Gregory 1998; Moynihan 1969; O'Connor 2001; Self 2003). Here I want to chart how Oakland's "Mexican American community" came into existence out of competition for War on Poverty funds. This mobilization emerged through a tactful negotiation with different state agencies and a carefully crafted relationship with African Americans. In their negotiations with California state and federal agencies, Mexican American community leaders organizationally rendered Oakland's Spanish-speaking community credible as rights-bearing residents and positioned the organizations 
they had created as their stewards. Like their African American counterparts, Mexican American political organizations mobilized to become agents in the rapidly expanding market of federally funded, place-based solutions to poverty. They reinterpreted the War on Poverty agenda and helped guide their community by marshalling a commitment to efficient care and guidance of the growing Spanish-speaking population.

\section{GOVERNING THROUGH DEVOLUTION AND ASSOCIATIONAL PRACTICES OF MEETING COMMUNITY NEEDS}

By making the local community and private entities, such as community-based organizations, the primary agents in charge of planning and organizing antipoverty measures, the War on Poverty set an important precedent to the current neoliberal trend of devolution. It is now well recognized among scholars of the state that one of the important federal policy shifts undertaken during the presidency of Ronald Reagan between 1981 and 1989 was the devolution of the spending of public funds and resources from the federal government to states, counties, and municipalities (Collins et al., 2008; Marwell 2004). This devolution was part of a larger neoliberal practice that accelerated the state's retraction from New Deal and Great Society social services such as education, health, and support of the poor (Brenner and Theodore, 2002, 2003; Hackworth 2007; Harvey 2005; Saad-Filho and Johnston, 2005). Studies of American poverty influenced by Michel Foucault's analytic of governmentality further argue that neoliberalism devolves the responsibility of the state to individual citizen-subjects by normatively constructing individuals as entrepreneurial actors in every sphere of life (Brown 2006; Ong 2003). Subjects are expected to self-care and to take responsibility for their own needs and ambitions (Rose 1999). A pivotal component of this trend in relationship to urbanization is the reconfiguration of the territory of government from the nation-state to the level of community and the reliance of non-state agencies to help construct productive and entrepreneurial subjects (Ferguson and Gupta, 2002; Ong 2003; Raco and Imrie, 2000). Proponents of devolution couch the transfer of responsibility to local municipalities and non-state agencies in a language of empowerment that portrays these localized arenas as the best sites of productive and positive action (Raco 2003).

The War on Poverty was such a devolutionary project that transferred the problem of poverty from the federal government to local communities and ultimately to individual subjects. As Marris and Rein (1967) argue about War on Poverty efforts, the "devolution of power extends beyond any formal jurisdiction to the citizen himself. He is expected, ideally, to be an active promoter of the well-being of his community-his children's school, the amenities of his block, neighborhood affairs" (p. 9). Much of the development of this devolutionary shift came from the programmatic agenda of the Ford Foundation Gray Areas Program, which as reported in the Oakland Tribune (1962), had selected Oakland in 1961 as one of three pilot cities to receive a $\$ 2$ million grant to help forge an "all-out attack on the social problems of minority groups and the proper assimilation of new citizens into the community" (p. 1). The program targeted the Castlemont district of East Oakland, which was deemed a "transition area" due to the outmigration of White middle-class residents and their replacement by lower-income Blacks, resulting in what analysts of the time called "social disorganization" (Rhomberg 2004, p. 135; Salzman 1963). The program's objective was to prevent this neighborhood from becoming a "Negro ghetto" by conscripting community participation though a formalized citizens' advi- 
sory committee and coordinating existing city services through the Oakland Interagency Project (OIP). Neighborhood citizen participation coupled with the coordinated support of city agencies became the cornerstone of the Gray Areas Program. The local community represented both the target of intervention and the agents responsible for bringing about the desired change (O'Connor 1996, 1999).

The Gray Areas Program, according to O'Connor (1996), signaled the first shift away from structural and economic reform as a way of alleviating poverty to a concentration on individuals and their behaviors. Focused on assimilating once rural Black populations to urban life, the object of antipoverty programs was to transform deficient Black subjects into self-governing urbanites. The Gray Areas Program and subsequent War on Poverty, explains O'Connor (1996) “perpetuated the notion of poverty as a problem confined to other people and diverted attention from its links to economic restructuring, population movements, racial discrimination, and government policies that perpetuated inequality" (p. 617).

A shift in focus to individuals and in changing peoples' behaviors required the recruitment of different local agencies-both state and non-state- to run projects to govern the conduct of the poor and other subjects who were viewed as deficient. With the goal of achieving the overall welfare of the population, the federal War on Poverty governed at a distance and expanded its reach among the poor by tactically granting authority to local communities, albeit within a limited field of possible actions.

The Community Action Program (CAP), started in 1964 by the Economic Opportunity Act, was the centerpiece of this agenda and mobilized community members through non-state, usually private nonprofit organizations, known as Community Action Agencies (CAAs) (Cruikshank 1999; Jackson 1993). Rather than sending War on Poverty monies to states or to municipalities as grants, the federal government allocated them to the newly established, independent Community Action Agencies (Clark 2000; Marwell 2004, p. 268). The CAA theoretically administered a diverse collection of over a thousand federally funded, local, neighborhood-based antipoverty agencies whose mission was to coordinate existing social services and bring new services closer to the poor. As in the Gray Area program, the federal government privileged associationalist practices which promoted a new and powerful role for non-state agencies like CAAs in combating poverty (O'Connor 1999). At the local level, federal policies also encouraged nonprofit community service organizations to expand their existing activities by contracting with the Office of Economic Opportunity $(\mathrm{OEO})$ and competing for federal grants.

The devolutionary practices of the War on Poverty, however, were fundamentally limited from the onset. Employing the famous motto of "maximum feasible citizen participation," War on Poverty efforts employed an unrealistic language that sought to empower communities and individual citizens to become agents in the development of their own communities (Kramer 1969; Moynihan 1969). According to the Office of Economic Opportunity (1965) Community Action Program Workbook, community action agencies were organizations "established at the local community level to direct and coordinate the attack on the complex of poverty problems found in the given community" and were to serve as "catalyst and coordinator, acting to bring about change and to mold diverse activities into a smooth, effective instrument for reducing and eventually eliminating poverty in the local community" (p. 10). This dual role of catalyst and coordinator bestowed individual Community Action Agencies with enormous responsibility and required that community members, most of whom had minimal educational and organizational training, to act as a cohesive administrative entity (Kramer 1969). 
Oakland's Community Action Agency was troubled from the onset because of lack of training, difficulty in acting as a cohesive entity, and disputes with citygovernment. Black middle-class leadership which dominated the CAA also came into conflict with working-class Black sentiments and goals (Pressman 1975). As O'Connor (2001) writes, the federal government never fully clarified the meaning of "maximum feasible citizenship participation" or articulated how much decision-making power would be granted to individual citizens (p. 133). In fact, the idea of mobilizing communities as political and programmatic entities was an ideal without much of a proven record (Kramer 1969; O'Connor 1996; Williams 1975). According to Ralph Kramer's (1969) study of war on poverty programs in the San Francisco Bay Area, this mobilization of the local community proved to be a disaster in actual practice. However dystopic the devolutionary practices were, they represented a moment of opportunity for community-based organizations and existing leaders to render poverty in Oakland as an identifiable, researched, and necessary target of governmental improvement programs. African American middle-class professionals took control over Oakland's CAA and utilized it to expand opportunities for the Black population and, according to Rhomberg (2004), "facilitated their own political entry into the new institutional forms of the regime" (p. 139). For Mexican American leaders in Oakland, the War on Poverty helped strengthen their organizations by bringing disparate groups together, and by so doing bolstered their demand for access to antipoverty funds and programs and their more equitable distribution.

\section{THE COUPLING OF POVERTY AND BLACKNESS AND THE CONSOLIDATION OF A MEXICAN AMERICAN MOVEMENT IN OAKLAND}

The federal government envisioned the War on Poverty, at its creation in 1964, as a program of empowerment aimed at the "poor" (Cruikshank 1999). While the "poor" brought together disparate racial, gender, and generational segments of the population, numerous scientific ${ }^{5}$ and authoritative studies of the time came to define poverty as synonymous with African American disadvantage (Marris and Rein, 1967; Nichols 1966; Record 1963; Salzman 1963; Wood 1968). Studies overwhelmingly reported that "Negroes" suffered far greater unemployment rates than Whites as well as diminishing incomes; these studies employed a culture of poverty analysis that justified a coordinated front of job, educational, and other skills-development programs intended to transform deficient subjects into respectable urban dwellers (Marris and Rein, 1967; Nichols 1966; O’Connor 1996; Record 1963; Self 2003).

Within these poverty formulations, researchers deemed Mexican Americans a nebulous third group in between Blacks and poor Whites. Categorized as "whites with Spanish surnames" by 1960, 6.5\% of Oakland's population had Spanish surnames and constituted one-fourth of the non-White minority group (Bernardi 1965, p. 1). Compared to African Americans, Mexican Americans were far more dispersed and not confined to a single geographical region. Bernardi (1965) found that Mexican Americans, like African Americans, were over-represented among the unemployed and poor and had the lowest levels of educational attainment of any group. While researchers acknowledged the importance of studying the growth of the Mexican American population and poverty, influential studies such as those of Dr. Wilson Record of the University of California, Berkeley and research director of Oakland's Gray Areas Project held that emphasis on studying "Negro" poverty and disadvantage was most pressing. As Record (1963) wrote "The Negro population is relatively new to the Bay Area, whereas Mexicans have been a familiar site for a long time" 
(p. 1). As new migrants from the South and Southwest, Dr. Record argued "Negroes ... have a salient conspicuousness, their semi-rural traits standing out even more sharply against the Bay Area urban backdrop because of their color" (p. 1). Dr. Record's findings thus recommended that Blacks merited more immediate consideration in poverty studies.

Poverty researchers and program administrators also explicitly overlooked Oakland's Spanish-speaking residents because they were not perceived to symbolize the threat that Blacks did. As early as 1963, for example, the Oakland Tribune reported on Dr. Record's study in which he warned that San Francisco Bay Area communities had either to "make room" for Blacks or face the threat of a "growing number of Angry black men" (Irving 1963, p. 8). Estimating a doubling of the Black population by the 1980s, Black-White relations, Dr. Record (1963) argued, would become the racial tension most critical to San Francisco Bay Area communities. What was particularly worrisome, noted Record (1963), was the "social and political militancy of Bay Area Negroes, in contrast to the passivity or mild protest of the Chinese, Japanese, Indians, and Mexicans" (p. 2).

War on Poverty efforts theoretically conceived of the poor as composed of diverse groups. In practice, cities like Oakland with a prominent African American population officially equated poverty with Blackness, and accordingly funneled antipoverty funds predominantly towards alleviating African American disadvantage. Oakland's Spanish-speaking community quickly understood this and organized en mass to prevent their continued marginalization in the contest over federal War on Poverty resources. They did this by building on a long history of community-based organizing and by allying themselves with important sectors of the African American Democratic Party establishment. Organizations such as the Community Service Organization (CSO), the Mexican American Political Association (MAPA), the American G. I. Forum, and religious groups had represented the Mexican American population for decades, primarily in West Oakland and in the Fruitvale neighborhood. These organizations came into existence focusing on small-scale, membershiprun, neighborhood-improvement campaigns aimed at citizenship participation and leadership development. They had built relationships of trust with the Mexican American population in Oakland that allowed them to at once help care for and direct their constituents to integrate their Mexican American barrios with the broader society - an integral component of the assimilationist goal of War on Poverty programs.

\section{Post-World War II Mexican American Organizing}

Oakland's postwar organizing had its roots in a small but active Spanish-speaking Catholic movement that focused on developing religious and social services for Mexican Americans. Created by radical priests such as Father Gerald Cox, Father Charles Phillips, and Father John Ralph Duggan, this church-based movement began by creating Spanish-language masses, next fostering self-help projects including after-school programs for youth and assistance for poor families. These priests maintained that the best way to live as Christ had was through fighting for the poor and oppressed while simultaneously linking Oakland's Spanish-speaking residents with Mexican Americans throughout California (Cox 2006). As long-term activist Elvira Rose (2011) recounts, the priests "used to go up and down California's Central Valley organizing people in the small towns." Through these activities, Oakland church groups networked with rural towns and the farm worker struggles throughout California. By so doing, noted CSO leaders Elvira Rose, Herman Gallegos, and Alex Zermeño, the church was also instrumental in providing the guidance and 
organizational base to build secular organizations such as the CSO in Oakland (Zermeño 2011).

Alongside these Catholic groups emerged a cadre of regional offices for organizations such as the League of United Latin American Citizens (LULAC), the American G.I. Forum, and the Community Service Organization (CSO), which developed in the post-World War II period and were committed in an integrationist agenda. LULAC was officially funded on February 17, 1929 in Corpus Cristi Texas with the mission of improving the appalling conditions of poverty and civil rights abuses facing Mexican Americans. As Gutiérrez (1995) writes, from its inception, LULAC's constitution emphasized that the best way to overcome these conditions was to organize as American citizens, even to the extent of excluding unnaturalized Mexican nationals (p. 77; Acuña 2004). The G.I. Forum was established by a group of Mexican American veterans in 1949 and like LULAC, Gutiérrez (1995) reports, it argued strongly that civil rights efforts must be focused on U.S. citizens of Mexican descent (p. 155). While these organizations claimed that they were nonpolitical associations, they were both active in political issues from the onset. Founded in Los Angeles in September 1947, the CSO was the first organization that promoted cooperation between Mexican Americans and Mexican immigrants. Unlike the G.I. Forum and LULAC, the CSO had no citizenship requirements for membership and often encouraged noncitizens to join. As Gutiérrez (1995) states, the CSO made naturalization of noncitizen members a priority and radically expanded its organizing campaigns to incorporate resident Mexican aliens whom they understood not as sojourners but as integral members of the Mexican American community (p. 170). As historian David Gutiérrez further argues, the post-WW II period "marked a significant victory for Mexican American activists and organizations that had pursued an integrationist civil rights strategy. These organizations shrewdly manipulated a wartime rhetoric shaped by discussions of human rights and the self-determination of peoples that dominated domestic and international political discourse" (p. 152). This agenda significantly impacted the claims-making process of an expanding collection of organizations, advocacy groups, and mutual aid societies that began to dot the U.S. Southwest.

Building on the work of radical priests in the Catholic Church, the Community Service Organization (CSO) was a group that played a large role in organizing Mexican Americans after 1945. Founded by Fred Ross, Antonio Rios, and Edward Roybal with the support of Saul Alinsky's Industrial Areas Foundation, the CSO became the training ground for the first generation of Mexican American leaders, including Cesar Chavez, Dolores Huerta, and Gilbert Padilla (Acuña 2004; Gallegos 1989; Gutiérrez 1995; Orozco et al., 2008). The CSO grew rapidly in California. By the early 1960s, Acuña (2004) writes, it had thirty-four chapters with a total of 10,000 dues-paying members (p. 279), but as a grassroots organization it had little institutional support and meager funds.

Portrayed by reporter G.W. Sherman of The Nation in 1953 as the source of the "political awakening" of the Spanish-speaking minority, the CSO endeavored to transform a "relatively voiceless element in the community into an integrated responsible segment of society" (p. 256). It did so by concentrating primarily on the training of indigenous leaders who were taught to engage in self-help efforts such as neighborhood physical improvements, voter registration, education, housing, and other civil rights projects. ${ }^{6}$ The CSO believed that community development happened only first by building internal leadership (Gallegos 2011). In a classic integrationist move, CSO leadership hoped to enlist its membership in a democratic project and to guide them to participate fully in all aspects of American society. The CSO 
was committed to giving voice to Mexican Americans as virtuous agents of change in society.

By 1956, the Oakland CSO chapter had 143 dues-paying members and a regular attendance of about seventy-five people at general assembly meetings. The chapter's services included a voter registration program that worked with the Voters League of Alameda County. Education was a prominent component of the organization's activities, which included citizenship, basic ESL, and Spanish language classes led by the head of the educational committee who was a teacher at the Oakland Public Schools (CSO 1956a). In both its educational programs with youth and adults and its voterregistration drives, the $\mathrm{CSO}$ was bestowed with an immense responsibility not just to provide for the Mexican American community, but also to direct this community in a particular fashion. It did so by creating relations with already existing city services and by guiding its membership in the use of these services.

In 1954, the CSO became a national organization whose objectives as reported in the Los Angeles Daily News (1954) were "to coordinate efforts for the common good of the community" and "encourage active participation of neighbors in civic life and to improve relations among all races, nationalities, and religions" (p. 3). Believing in the power of the vote to leverage demands and reap the promises of democracy, the CSO equated voter registration with progress (CSO 1956b). It maintained that voter registration drives would "build sufficient community bargaining power throughout the Spanish-speaking neighborhoods to command the attention of the public and private officials who [were] in the position to assist in the neighborhood improvement and group advancement. ${ }^{\text {"7 }}$ Voter registration and voting, for the CSO, were the conduits to obtaining help from outside the community. The CSO, however, was not in the business of running political campaigns. Instead, it served to leverage the Mexican American vote to attain demands from government representatives and elected officials (Gallegos 2011).

\section{Forging Unity, Building Institutional Presence: The Mexican American Unity Council}

At the height of federal investment in the War on Poverty, between 1964 and 1968, Mexican American organizations sought recognition and compensation for their labors in community development. Given that the federal government distributed War on Poverty funds at the local level and encouraged nonprofit organizations and local state agencies to vie for these monies, Mexican Americans were concerned they did not have enough of an institutionalized presence or history to effectively compete for this funding. At the time, most of the existing organizations, like the CSO, were storefront membership-based groups without state and private foundation fiscal support. As Orozco et al. (2008) report and Arabella Martinez, the first executive director of the Mexican American Unity Council, ${ }^{8}$ describes, "The concern underlined the need for [Mexican American] leaders to collaborate and form a united front and build a local movement. The Mexican American Unity Council was designed to bring together activists and groups and build a cohesive agenda" (p. 15). Building a critical mass required transforming groups such as soccer clubs, church congregations, and brotherhood associations into politicized entities that fit the federal requirements necessary to qualify as War on Poverty Community Action Programs.

Mexican American activists understood that to attain War on Poverty funding, they had to tap into the power of African Americans. In the postwar years, African Americans had made tremendous inroads into city offices, in the Democratic Party, and had garnered substantial political clout in Oakland (Rhomberg 2004; Self 2003). 
According to Rhomberg (2004), this was symbolized by the 1954 founding of the Men of Tomorrow, a civic service club of Black business, professional, and religious leaders (p. 123). In addition, as Gallegos (1989) writes, African Americans had institutionalized groups like the Urban League and the National Association for the Advancement of Colored People (NAACP) which accomplished a plethora of civil rights gains that helped them garner legitimacy among the White establishment (p. 33). In Oakland, prominent Black businessmen and politicians were committed to ensuring the advancement of Blacks and understood the War on Poverty to be the fruit of their civil rights struggles.

Mexican Americans in Oakland accordingly turned to African Americans leaders with whom they had worked and whom they counted among their friends (Gallegos 1989; Grillo 2000). They relied on two key figures-Jimmy Delgadillo and Evelio Grillo-who both had affiliations with the CSO and the City of Oakland (Gallegos 2011). A community leader extraordinaire and competitive boxer, Delgadillo had been born in West Oakland and grew up with many of the Black leaders of the time. He was a childhood friend of William Byron Rumford, the first Black elected official in Northern California, and others who represented Black Democratic power. Evelio Grillo was an Afro Cuban immigrant who spoke Spanish and was well connected with the city's African American elite and served as assistant to D. G. Gibson, who became one of the foremost leaders of the California Democratic Party (Grillo 2000). These two figures, both because of their African heritage and having grown up alongside African Americans, played tremendous roles of linking these two communities. According to Mexican American activists of the time, forging alliances with these African American leaders was seen as crucial to gain access to War on Poverty program monies.

With support from African American leaders, Mexican Americans began to claim the need to have their own linguistically and culturally autonomous spaces for community organizing. The formation of the Mexican American Unity Council in 1964 represented this concerted effort to consolidate existing Spanish-speaking organizations to collectively represent Mexican Americans in War on Poverty related negotiations. One of the initial actions of the Mexican American Unity Council was to create a Spanish-speaking advisory group in 1966. According to Jack Ortega (1966), the chairman of the Unity Council, "[F]or the first time, the poverty program was explained to these people, and they were made to feel that there was a place in it for them." In a letter to the head of the Oakland Community Action Agency (CAA), Ortega (1966) extolled the success of the meeting:

The group is expanding rapidly, and wishes to continue on this basis-not because we want to isolate ourselves from other minority groups, but rather because we feel that, in this way, we can best resolve the problems of communication and cultural differences that are peculiar to the Spanish-speaking people of this area.

Mexican American community groups understood that their cultural and linguistic differences made it difficult for them to adequately participate in the larger society as full participants. By representing the Mexican American community and fostering culturally inclusive meeting spaces, leaders sought to address and direct the demands of this population.

This mobilization by community organizations resulted in the establishment of a special Spanish-speaking Target Area Advisory Committee by the City of Oakland Community Action Agency_popularly known simply as the "poverty board." This 
was a significant accomplishment given that Oakland's Target Area Advisory Committees (TAACs) were designed to represent communities in four geographic areas: East, North, West Oakland, and Fruitvale. The fifth TAAC, which became known as the Fruitvale Spanish-speaking Committee, was the only one defined by language and culture. The committee ultimately challenged the geographic definitions of antipoverty programs and demanded the recognition of Oakland's Spanish-speaking population. Mexican American groups argued that unlike African Americans, Spanishspeaking residents were not confined to one specific geographical location; they were dispersed widely throughout the city and beyond (Brasher and Martinez Springer, 1966; Wood 1968). While War on Poverty stipulations privileged "community" as the unit of analysis, it emphasized a geographic, place-based understanding of organizing and belonging. For Mexican American leaders, community was far more than geography, uniting an ethnic/racial collective that cohered around a shared agenda of social, cultural, and political improvement throughout the Southwest. By accentuating their differences in terms of culture, geographical distribution, and language, Mexican American organizations unsettled antipoverty efforts that focused solely on geographic notions of community.

Mexican American admission into War on Poverty programs quickly transformed organizations like the Unity Council and altered their activities. While Oakland's Unity Council started as a political action group it soon became an institutionalized social services provider to ensure that Mexican Americans in the Fruitvale received the assistance that they needed. As a service-providing organization, the group was able to attain important antipoverty funding that allowed it to create various programs including Education for Advancement which offered ESL classes. The Unity Council also established a separate 501 (c)(3) nonprofit organization, the East Bay Spanish Speaking Citizens Foundation (EBSSCF), as a service provider agency. In addition, it became the host of Oakland's first Latin American library which offered books in the Spanish language and was funded through a direct grant of $\$ 100,000$ of federal antipoverty funds (Pressman 1975). The California Department of Labor established one of its employment service centers in Oakland's Unity Council office, working with the Council to ensure that Spanish-speaking residents could access the deluge of job training programs created by War on Poverty funding (Rose 2011). This was a significant accomplishment because before the establishment of the Unity Council no social services existed in Oakland that targeted Spanishspeaking residents (Orozco et al., 2008). The Unity Council became an institutionalized presence in Oakland, serving as both an advocacy group and a meeting point for different community services.

Utilizing their own research and distributing their own authored community reports, the Unity Council and other Mexican American groups quickly gained legitimacy among existing state and federal agencies. Given the invisibility of Mexican Americans in government-funded poverty studies, Mexican American organizations contested these studies by conducting their own research. They leveraged their own authority on the needs of Spanish-speaking residents to forge a cohesive programmatic agenda for their constituency and in the process created a distinct target of government-the Mexican American community. In 1965, for example, representatives of MAPA, CSO, and the Mexican American Unity Council worked together with the City of Oakland to produce a report entitled "Staff Report of Mexican American Community Development Survey and Resulting Proposal" (City of Oakland 1965). The report was the product of months of interviews and collaboration between different Mexican American organizations and City of Oakland staff members. It revealed the lack of access Mexican Americans confronted in gaining city 
services and recommended the creation of bridging programs to connect Mexican Americans to existing city and state services. In this proposal, Mexican American nonprofit leaders envisioned a comprehensive package of care rooted in cultural revitalization, empowerment, and inclusion in the broader U.S. culture. Their proposal sought to "inculcate in the Spanish surname community a pride in its historical and cultural heritage" (City of Oakland 1965). To do so, leaders hoped "to create in the people an awareness that their forebears played an outstanding role in the exploration, settlement and development of this country and in contributing to the establishment of its institutions" (City of Oakland 1965). Mexican Americans did not need to feel excluded from access to civic services; they were entitled to these benefits because they themselves had helped to create them, armed with a sense of pride in their culture and their rightful claims as citizens. In their negotiations with the city of Oakland, leaders thus gave coherence to the term "Mexican American community" for the first time and articulated a set of mutually shared interests, needs, and desires.

The formalization of the term "Mexican American community" was at once a valorization of Mexican culture and language heritage, and also an homage to the important contributions Mexican Americans had made in the United States. This was a specific response to official U.S. Census usage of terms such as "whites with Spanish surname" that leaders claimed led to the undercounting of the Mexican American population. In Oakland, Mexican Americans' widespread identification as Spanish-speaking allowed them to ally with other groups such as Puerto Ricans and Filipinos who spoke a common language. However, this language-based identifier did not adequately portray the racial/ethnic experiences of discrimination and inequality particular to Mexican Americans. Like African Americans, Mexican American leaders also understood the War on Poverty to be a form of compensation for racial injustices of the past. The term "Mexican American community" sought to solidify their position as a group that shared experiences of racialized oppression and inequality.

To further attract the attention of state and city agencies, Mexican American Political Association (MAPA) and CSO representatives including James Delgadillo, Bert Corona, and Edward Quevedo also involved themselves in expanding Mexican Americans as a voting block. MAPA was formed in 1959 and committed itself to provide an environment "through which the Mexican American can channel his political efforts and demands" (Delgadillo 1965). MAPA leaders envisioned themselves as stewards in the proper political guidance of the Mexican American population. According to James Delgadillo's letter of July 16, 1965 to Anthony Barbieri of the U.S. Department of Labor, MAPA possessed "special resources which consist of organized statewide rank-and-file citizens, who have had useful work experiences within and offer real hope for the progress of a million Americans of Mexican descent in California" (Delgadillo 1965). Bestowed with "special resources" developed through extensive experience organizing, MAPA claimed it could mobilize a contingency of "organized rank-and-file citizens [which included] . . . a considerable number of young and determined leaders . . capable of transposing the responsibilities of citizenship to persons of bilingual cultural background and instill in said persons the incentive to contribute to the fullest extent of their abilities in furthering the vitality of our economical and social betterment" (Delgadillo 1965). Not only did MAPA's leadership have extensive organizing experience, they also claimed they could mobilize a "million of Americans of Mexican heritage." Mexican American leaders thus sought to harness the social, economic, cultural, and civic improvement of Spanish-speaking residents by directing them in the appropriate political path. 
Mexican American organizations took seriously their role as mediators between the Mexican American population and different state agencies. In their exchanges with state agencies such as the California Department of Employment, the City of Oakland, and federal antipoverty offices, Mexican American leaders requested that these agencies be sensitive to the needs of a rising Mexican American population but also informed them that they were prepared to guide the community to vote in a particular fashion and to empower them as citizens for full civic participation.

\section{GOVERNMENT AND ITS IMPACTS ON MEXICAN AMERICAN ORGANIZING STRATEGIES}

By accepting federal antipoverty funds, Mexican American organizations became at once agents of government as well as subjects of the state's governmental technologies. Organizations like MAPA, the Unity Council, and the CSO enacted practices of government by guiding their constituents along the rightful path of "true" U.S. citizenship. They branded themselves to different state and federal agencies as capable of shaping exemplary and even obedient citizen-subjects. And though not explicitly stated, Mexican American obedient subjects were almost always implicitly contrasted to disobedient and even "radical" Black subjects. This was of course all in the name of attaining specific resources from state agencies and as a means to leverage political contacts.

The Federal government promoted a specific type of incorporation into its new schema of localized welfare provision. As Stephen Gregory (1998) has argued for Black leaders in New York, the War on Poverty attempted to incorporate activists into a "new genre" of state-sponsored institutions and relations (p. 86). Mexican American leaders in Oakland learned the modes of comportment around state officials and the bureaucratic means to accomplishing particular tasks. These leaders created institutionalized bureaucratic organizations such as the Mexican American Unity Council that could compete for federal and state funds. They also learned the suitable modes of conducting public protest and the appropriate bandwidth of radicalism they could employ. As Foucault explains, governmental forms of power do not seek to eliminate a particular activity or occurrence. Instead, government focuses on maintaining an appropriate range of permissible behaviors and actions (Foucault 2007). The art of government is not about forcing subjects to do the will of some kind of authority figure or sovereign, but rather encouraging them to choose certain paths over others, guiding conduct towards one end while limiting other possibilities.

Mexican American groups accordingly navigated a social movement terrain already heavily contoured by African American protest, exerting its own political technologies on Mexican American activism. To effectively speak the language of racial/ ethnic rights in the 1960s, Mexican American activists understood they had the duty to ally with African Americans as racialized subjects. They also carefully crafted a history of their experiences of inequality based on an existing language of civil rights and protest which African Americans had codified through negotiations with the state. Mexican American groups celebrated and in fact emulated both the civil rights gains of African Americans and the urgency of the emergent Black Power movement. However, they clearly understood both the potential openings of each movement strategy as well as the limitations of militant and radical practices. While they supported a direct linkage with African American civil rights struggles and in fact collaborated with certain groups and campaigns, they also saw the limitations of this 
movement that did not place their own issues of language and immigration at the center of discussion.

In the 1950s, CSO representatives were part of a civil rights coalition that regularly met with Jewish, Black, Anglo, and trade unionist leaders to frame their collective strategy for public policy involvement in California. This formal coalition accomplished the Rumford Fair Housing Act in 1964 and earlier, in 1958, the Fair Employment Practice Commission (Orozco et al., 2008). In 1963 the Oakland CSO chapter publically aligned itself in a united front with the NAACP and Congress of Racial Equality (CORE) against discriminatory practices. The CSO formalized this position in 1963 during its Executive Board meeting in San Jose where it reaffirmed its national policy and openly advised that a violation of civil rights, or the denial of equal protection under the law, was a matter of historical concern to CSO, nationally, and at the chapter level. As a result of the CSO's work, twelve families received waivers of the citizenship requirement for admission to the City of Oakland Housing authority low-cost housing. The CSO committed itself to continuing the struggle for the elimination of this type of citizenship requirement, which it claimed served to "intensify the inequitable burdens on minorities who contribute to the growth and progress of the community" (CSO, 1963).

Oakland's CSO chapter saw civil rights abuses as a priority and justified alliances with African Americans based on their shared experiences with discrimination. A 1963 Oakland CSO newsletter, for example, acknowledged the formal partnership in antidiscrimination claims through a special feature entitled "El Momento Actual" [The Current Moment], written entirely in Spanish. Utilizing the imagery of brutality against African Americans in Mississippi and a language of compassion and urgency, the piece declared that Mexican Americans should be committed to support African American civil rights. CSO leaders in 1963 endeavored to convince their constituency that African American civil rights efforts were equally their struggles:

It should be noted that this is not a struggle of Negroes against whites although it might appear this way on the surface. This is something that affects all minority groups and it is fitting that we the members of other ethnic groups also make this struggle our struggle. Because we are all treated alike we must all identify with this struggle. We must not be mute witnesses or insensitive to another group's pain. Their pain is our pain at the same time that their gains are our gains. It is not just that we abandon that brave race (CSO, 1963). ${ }^{9}$

This is a clear example of how Mexican American organizations attempted to construct a shared sense of discrimination by a White oppressor, which they hoped would propel their constituents to defend the civil rights of all minority groups. Oakland's CSO chapter argued that in the Southwest, Mexican Americans overwhelmingly benefitted from "Negro" anti-discrimination efforts, such as drives against housing discrimination, and employment discrimination cases. Similarly, they acknowledged that Mexican Americans shared a parallel experience of police brutality and excessive surveillance by law enforcement. Oakland CSO members were encouraged not just to sympathize with African American struggles, but to also analyze experiences of disadvantage through the lens of their own civil rights abuses.

Oakland CSO activists were so adamant in their shared civil rights agenda that they ridiculed Mexican Americans from other regions who were allegedly hesitant to ally with African American struggles. A 1964 CSO newsletter featured an essay entitled "What is the Mexican American Doing in the Civil Rights Movement?" that critiqued the statements of an unnamed Mexican American attorney from Los Ange- 
les who worked for the State Attorney General's Office. The attorney described the sentiments of Los Angeles Mexican Americans regarding civil rights struggles in the following fashion:

With the tremendous Spanish surname population our group could be a potentially powerful force in the civil rights movement. However, in the past there has been a lack of participation by the so called grassroots. [T] here are some who have stated that the Mexican-Americans have no problems, others who have stated our problems are different from those of the Negro, and finally we have those who state that if we do have problems, that we should be left alone to solve them in our own manner (CSO, 1964).

Members of the Oakland CSO chapter were outraged by the article and declared that it was ridiculous to suggest that Mexican Americans in Los Angeles remained "selfishly concerned with what is or is not Mexican American, Spanish speaking vs. the problem of the Negro." The Oakland CSO Newsletter editors declared that these Mexican Americans had truly lost sight of the problem confronting them and asked: "[h] ave they not seen discrimination in Public Housing, Accommodations, Education and Employment?" The editors were so concerned that they jokingly stated: "Perhaps, it is the music from the Mariachis that blinds them" (CSO, 1964).

The scolding tone of these newsletters can also be read to illustrate the reservations some Oakland-based Mexican Americans had about allying themselves with African American movements. It is not at all surprising that Oakland Mexican American organizations would support African American civil rights struggles, given the degree of friendships and formal relations they had with prominent African Americans. Most revealing are the Mexican American organizers' emphatic and dedicated attempts to convince their constituents that such alliances were not only necessary but also a matter that directly affected them.

Some organizers feared that associating too closely with African American civil rights would render issues of language discrimination, culture, and immigration of less import. CSO representatives agreed that while the problems of Spanishspeaking groups were not as "exacerbated as the Negro's," their concerns were complicated by the additional fact that many spoke mainly Spanish and thus required different kinds of mobilizing strategies and agendas (CSO, 1964).

As former CSO leader Herman Gallegos (1989) noted:

[T] he issue of color discrimination was much more severe for blacks.... Hispanics were an unknown quantity. We had to overcome the language barrier and the citizenship barrier to become a potent political force so as to get attention. It wasn't because blacks didn't want it; it was just simply that we had to do our own development (p. 35).

While most Mexican Americans thus did not question supporting a shared civil rights agenda with African Americans, certain sectors were cautious of the organizational means employed.

Emphasizing their rightful participation in all aspects of American society as citizens, Mexican American leaders urged their constituents not to embark on a radical separatist approach akin to the Black Power movement. Instead, leaders wholeheartedly critiqued organizational practices that did not respect an integrationist approach centered on active citizen participation through formal political processes. In a 1966 MAPA newsletter, for example, president Eduardo Quevedo cautioned 
an expanding constituency about engaging in a separatist radical movement: "Much is heard today of Black power, non violence versus violence or self defense . . . for us Mexican Americans and other Spanish-speaking people in California the idea and slogans of Brown Spanish-speaking Mexican American Power is being suggested as a new slogan." While welcoming a new militancy in demanding Mexican American appointments to government and policy-making positions, MAPA admonished militant leaders who discouraged voter registration campaigns. "Today we are hearing many well intentioned Mexican Americans shouting 'we are not going to register any voters unless we get money from the party . . . or unless we make COPE come across with some money.'" Quevedo (1966) warned of the danger of this approach: "MAPA [was formed] because we had not the 'power' to bring about some significant changes about our living conditions and relationships in our society." For Quevedo, change was only possible "through active political participation" and exerting pressure "by the Mexican American community in the area of policy making." True to this integrationist agenda of the post-World War II period, MAPA readily privileged formal political processes and rightful participation in democratic lobbying as the core values of Mexican American organizations. MAPA and other organizations constructed this idealized practice of citizenship, which they argued could only be employed in a manner that respected the democratic and peaceful principles of the movement.

\section{CONCLUSION}

Though War on Poverty programs had many limitations from the onset, they constituted unique political and institutional openings for local-based organizations and political action groups. As a devolutionary governmental program, the War on Poverty set up the architecture for the inclusion of non-state entities-communitybased nonprofit organizations - into a new schema of welfare provision. This served to transform grassroots movements into institutionalized federally recognized taxexempt nonprofit agencies. This process shifted organizational goals from leadership development and advocacy to the proper management of programs and community development projects and aided in subduing the urgency and rising militancy of grassroots protest.

Robert O. Self's (2003) American Babylon has argued that for African Americans in Oakland, War on Poverty efforts "constituted a discrete phase in the evolution of black political capacity" and transformed Oakland's political culture (p. 200). In this essay, I have sought to describe how the War on Poverty catapulted Mexican Americans into political action. Not unlike their African American allies, Mexican Americans also deployed the War on Poverty agenda of empowerment to build leadership capacity and to consolidate disparate Spanish-speaking organizations into a united Mexican American movement. The War on Poverty did not initiate Mexican American activism; rather, it served to consolidate already active political organizations which transformed themselves into institutionalized entities that guided the Spanishspeaking population and leveraged their pastoral technologies of government to represent, care for, and constitute the Mexican American community.

Through different culture-based projects of empowerment, Mexican American community-based organizations set in place specific power relationships. As Barbara Cruikshank (1999) reminds us: "Whether inspired by the market or by the promise of self-government and autonomy, the object of empowerment is to act upon another's interests and desires in order to conduct their actions toward an appropriate end" 
(p. 69). Bestowed with responsibilities of care that included bridging relations between the state and the Mexican American population, organizations enacted governmental technologies of their own. These political techniques deployed the language of "empowerment" prioritized by federal antipoverty programs, but rendered it Mexican American by suturing it with a project of cultural revitalization.

Enacting diverse culture-mediated technologies of citizenship, the leaders of community-based political organizations sought to educate Mexican Americans about their shared interests; interests that parroted the state's integrationist agenda of democratic civic engagement. However, whereas War on Poverty programs focused on individual attainment, whether through job training, educational advancement, and self-development programs, Mexican American groups insisted on achieving a collective improvement. These organizations thus enacted relations of government that both constituted and fundamentally transformed not a universal citizensubject but rather a collective of Mexican American subjects. This collective of Mexican American subjects as well as the demands, organizational tactics, and relationship to the state enacted by these organizations emerged through a carefully crafted relationship to both the Civil Rights Movement and Black radicalism of the time.

Mexican American political mobilizations of this period unsettled both the geography of race and poverty in Oakland. They challenged the automatic conflation of poverty with Blackness and began to articulate their own unique experience of racial inequality and poverty that differentiated Mexican Americans from Blacks. By stressing the importance of issues of language and culture discrimination as well as experiences of international migration, Mexican American leaders cultivated their own organizing agendas and programmatic efforts. This historical account of the political formation of the Mexican American community offers an important window into the study of changing racial/ethnic dynamics in post-World War II Oakland beyond the Black and White binary. The War on Poverty was thus an important period for the consolidation of Mexican American institutions such as the Unity Council and other community-based organizations that continue to provide services and guide Mexican American and other Latino constituents in Oakland.

Corresponding author: Juan Herrera, Department of Ethnic Studies, University of California, Berkeley, 506 Barrows Hall \#2570, Berkeley, CA 94720-2570. E-mail: jherrera@ berkeley.edu

\section{NOTES}

1. I would like to express my deepest appreciation to Donald S. Moore for his enduring support and guidance throughout the multiple stages of this project. Special thanks to Thomas Biolsi, Sara Ramirez, Teresa Gonzales, Carolyn Finney, and Jake Kosek for providing critical feedback on earlier versions of this manuscript. I thank the librarians at Stanford University's Department of Special Collections for their help throughout my data collection process. I would also like to thank the participants and organizers of the Race and Immigration in the American City Conference at the University of Chicago for their generative feedback and support. I am especially grateful for the edits and substantial comments from Ramón Gutiérrez. Support for data collection and analysis came from The University of California Institute for Mexico and the United States (UC-Mexus) and from the UC Dissertation Fellowship.

2. Consistent with the terminology of the time, I use the term "Spanish-speaking" to refer to people of Mexican American ancestry. Government officials, newspaper articles, and academic studies of the time commonly equated Spanish-speaking with Mexican American. Mexican American activists also preferred to use "Spanish-speaking" to ally with other groups, such as Puerto Ricans and Filipinos, that also spoke the Spanish language. 
3. The Treaty of Guadalupe Hidalgo was signed by the United States and Mexico on February 2, 1848 and ceded almost half of Mexican territory (which incorporated presentday states of California, New Mexico, Nevada, and parts of Colorodo, Arizona, Utah, and Oklahoma) to the United States. The treaty most notably guaranteed U.S. citizenship for Mexicans who inhabited the Southwest upon the United States takeover of Mexican territory (Acuña 2004; Gutiérrez 1995). The fact that activists referenced this treaty is a specific claim to their status as rightful citizens of the United States. As rights-bearing subjects, leaders positioned the Mexican American population as deserving of state welfare provisions.

4. Tania Murray Li (2007) defines "rendering technical" as a term to describe an ensemble of practices concerned with representing the domain to be governed as an intelligible field of action (p. 7).

5. As Michael Katz (1993) explains, the War on Poverty and the expansion of related government programs in the 1960 s created poverty research as a field in the social sciences because federal legislation mandated official evaluations (p. 14). See also O'Connor (2001) for a complete elaboration on the history of poverty knowledge as a social-scientific enterprise.

6. Address by Mr. Herman Gallegos (1964), Former National President of the Community Service Organization, to a Meeting of the Mexican American Political Association Executive Board.

7. Letter from Henry Nava (CSO Chairman) to Miss Consuelo Salcedo, August 10, 1949.

8. Consistent with the archival sources analyzed, I use the name Mexican American Unity Council to refer to this organization. However, by the late 1960s, the Unity Council officially became the Spanish-speaking Unity Council in order to make the organization more inclusive.

9. Translated by the author from Spanish.

\section{REFERENCES}

Acuña, Rodolfo (2004). Occupied America: A History of Chicanos. New York: Pearson Longman.

Bernardi, Gene (1965). Characteristics of the Spanish Surname Population in the City of Oakland. Oakland, CA: Oakland Interagency Project.

Brasher, Arlene E. and Arabella Martinez Springer (1966). Mexican American Recipients' Orientations Towards and Modes of Adaptation to the Welfare System. MA Thesis, Department of Social Welfare, University of California, Berkeley.

Brenner, Neil and Nik Theodore (2002). Cities and the Geographies of "Actual Existing Neoliberalism." Antipode, 34(3): 349-379.

Brenner, Neil and Nik Theodore (2003). Spaces of Neoliberalism: Urban Restructuring in North America and Western Europe. Malden, MA: Blackwell.

Brown, Wendy (2006). Edgework: Critical Essays on Knowledge and Politics. Princeton, NJ: Princeton University Press.

City of Oakland (1965). Department of Human Resources: Staff Report of a MexicanAmerican Community Development Survey and Resulting Proposal. Ernesto Galarza Papers, Box 14, Folder 8. Department of Special Collections, Stanford University Archives.

Clark, Robert F. (2000). Maximum Feasible Success: A History of the Community Action Program. Washington, DC: National Association of Community Action Agencies.

Collins, Jane L., Micaela di Leonardo, and Brett Williams (Eds.) (2008). New Landscapes of Inequality: Neoliberalism and the Erosion of Democracy in America. Santa Fe, NM: School for Advanced Research Press.

Community Service Organization (CSO) (1956a). Report from the Oakland CSO Chapter: March 15-July 15. Fred Ross Papers, Box 4, Folder 25. Department of Special Collections, Stanford University Archives.

Community Service Organization (1956b). Target for Progress Voter Registration Flyer. Ernesto Galarza Papers, Box 13, Folder 7. Department of Special Collections, Stanford University Archives.

Community Service Organization (1963). El Momento Actual. September Newsletter. Bert Corona Papers, Box 38, Folder 5. Department of Special Collections, Stanford University Archives.

Community Service Organization (1964). What is the Mexican Doing in the Civil Rights Movement? June Newsletter. Bert Corona Papers, Box 38, Folder 5. Department of Special Collections. Stanford University Archives. 
Corona, Bert. Papers. Department of Special Collections, Stanford University Archives.

Cox, Gerald F. (2006). The Radical Peasant. Victoria, CA: Trafford Publishing.

Cruikshank, Barbara (1999). The Will to Empower: Democratic Citizens and Other Subjects. Ithaca, NY: Cornell University Press.

Delgadillo, James (1965). Letter to Mr. Anthony Barbieri, U.S. Department of Labor. July 16. Ernesto Galarza Papers, Box 14, Folder 8. Department of Special Collections, Stanford University Archives.

Ferguson, James and Akhil Gupta (2002). Spatializing States: Towards and Ethnography of Neoliberal Governmentality. American Ethnologist, 29(4): 981-1002.

Foucault, Michel (2007). Security, Territory, and Population: Lectures at the College de France, 1977-1978. Mechel Senellart (Ed.), Graham Burchell (Trans.). New York: Palgrave Macmillan.

Gallegos, Herman E. (1964). Address to a Meeting of the Mexican American Political Association Executive Board. December 6. Ernesto Galarza Papers, Box 14, Folder 11. Department of Special Collections, Stanford University Archives.

Gallegos, Herman E. (1989). Equity and Diversity: Hispanics in the Nonprofit World. Oral history conducted by Gabrielle Morris. The Regional Oral History Office, The Bancroft Library, University of California, Berkeley, CA.

Gallegos, Herman E. (2011). Interview by the Author. August 2.

Galarza, Ernesto. Papers. Department of Special Collections, Stanford University Archives.

Gregory, Steven (1998). Black Corona: Race and the Politics of Place in an Urban Community. Princeton, NJ: Princeton University Press.

Grillo, Evelio (2000). Black Cuban, Black American: A Memoir. Houston, TX: Arte Publico Press.

Gutiérrez, David G. (1995). Walls and Mirrors: Mexican Americans, Mexican Immigrants, and the Politics of Ethnicity. Berkeley, CA: University of California Press.

Hackworth, Jason (2007). The Neoliberal City: Governance, Ideology, and Development in American Urbanism. Ithaca, NY: Cornell University Press.

Harvey, David (2005). A Brief History of Neoliberalism. New York: Oxford University Press.

Irving, Carl (1963). Bay Area Warned on Race Problem. Oakland Tribune, May 14, 8.

Jackson, Thomas F. (1993). The State, the Movement, and the Urban Poor: The War on Poverty and Political Mobilization in the 1960s. In Michael B. Katz (Ed.), The "Underclass" Debate: Views from History, pp. 403-439. Princeton, NJ: Princeton University Press.

Katz, Michael B. (1993). The Urban "Underclass" as a Metaphor for Social Transformation. In Michael B. Katz (Ed.), The "Underclass" Debate: Views from History, pp. 3-26. Princeton, NJ: Princeton University Press.

Kramer, Ralph M. (1969). Participation of the Poor: Comparative Communities Case Studies in the War on Poverty. Englewood Cliffs, NJ: Prentice-Hall Inc.

Li, Tanya Murray (2007). The Will to Improve: Governmentality, Development, and the Practice of Politics. Durham, NC: Duke University Press.

Los Angeles Daily News (1954). New National Organization Dedicated to Equal Rights. March 24,3 .

Marris, Peter and Martin Rein (1967). Dilemmas of Social Reform: Poverty and Community Action in the United States. Chicago, IL: Aldine Publishing Company.

Marwell, Nicole P. (2004). Privatizing the Welfare State: Nonprofit Community-Based Organizations as Political Actors. American Sociological Review, 69: 265-291.

Moynihan, Daniel P. (1969). Maximum Feasible Misunderstanding: Community Action in the War on Poverty. New York: Free Press.

Nava, Henry (1949). Letter to Miss Consuelo Salcedo. Fred Ross Papers, Box 4, Folder 9. Department of Special Collections, Stanford University Archives.

Nichols, William L. (1966). Poverty and Poverty Programs in Oakland: A Report to the Department of Human Resources of the City of Oakland. Berkeley, CA: Survey Research Center, University of California.

Oakland Tribune (1962). City Council Approve Top Posts for Ford Foundation. Febraury 16, 1.

Oakland Tribune (1966). Demands Made of City by Mexican Americans. April 15, 4.

O'Connor, Alice (1996). Community Action, Urban Reform, and the Fight against Poverty: The Ford Foundation's Gray Areas Program. Fournal of Urban History, 22(5): 586-625.

O'Connor, Alice (1999). Swimming Against the Tide: A Brief History of Federal Policy in Poor Communities. In Ronald F. Ferguson and William T. Dickens (Eds.), Urban Problems and Community Development, pp. 77-138. Washington, D.C.: Brookings Institute Press.

O'Connor, Alice (2001). Poverty Knowledge: Social Science, Social Policy, and the Poor in TwentiethCentury U.S. History. Princeton, NJ: Princeton University Press. 
Office of Economic Opportunity (1965). Workbook: Community Action Program. Washington DC.

Ong, Aihwa (2003). Buddha is Hiding: Refugees, Citizenship, the New America. Berkeley, CA: University of California Press.

Orozco, Manuel, Michael Austin, and Elaine Beale (2008). The Unity Council: Brief History of a Pioneering Community Development and Service Organization. Oakland, CA. 〈http:// www.unitycouncil.org/download/The\%20Unity\%20Council\%20History.pdf) (accessed August 9,2010).

Ortega, Jack (1966). Letter to Judge Lionel Wilson. Ernesto Galarza Papers, Box 14, Folder 8. Department of Special Collections, Stanford University Archives.

Pressman, Jeffrey L. (1975). Federal Programs and City Politics: The Dynamics of the Aid Process in Oakland. Berkeley, CA: University of California Press.

Quevedo, Eduardo (1966). MAPA Registration Newsletter. July 18. Ernesto Galarza Papers, Box 14, Folder 10. Department of Special Collections, Stanford University Archives.

Raco, Mike (2003). Governmentality, Subject-Building, and the Discourses and Practices of Devolution in the UK. Transactions of the Institute of British Geographers, 28(1): 75-95.

Raco, Mike and Rob Imrie (2000). Governmentality and Rights and Responsibilities in Urban Policy. Environment and Planning, 32: 2187-2204.

Record, Wilson (1963). Minority Groups and Intergroup Relation in the San Francisco Bay Area. In Stanley Scott (Ed.), The San Francisco Bay Area: Its Problems and Future, pp. 1-48. Berkeley, CA: Institute for Governmental Studies.

Rhomberg, Chris (2004). No There There: Race, Class, and Political Community in Oakland. Berkeley, CA: University of California Press.

Rose, Elvira (2011). Interview with the Author. May 2.

Rose, Nikolas (1999). Powers of Freedom: Reframing Political Thought. Cambridge, UK: Cambridge University Press.

Ross, Fred. Papers. Department of Special Collections. Stanford University, Stanford, CA.

Saad-Filho, Alfredo and Deborah Johnston (2005). Neoliberalism: A Critical Reader. London and Ann Arbor, MI: Pluto Press.

Salzman, Ed (1963). Castlemont's Laboratory of Life: City Reaps Core Area Study Benefits. Oakland Tribune, February 18, D19.

Self, Robert O. (2003). American Babylon: Race and the Struggle for Postwar Oakland. Princeton, NJ: Princeton University Press.

Sherman, G. W. (1953). Around the U.S.A.: A People Comes of Age. Nation, March 28, 256-256.

Weir, Margaret (1988). The Federal Government and Unemployment: The Frustration of Policy Innovation from the New Deal to the Great Society. In Margaret Weir, Ann Shola Orloff, and Theda Skocpo (Eds.), The Politics of Social Policy in the United States, pp. 149-190. Princeton, NJ: Princeton University Press.

Williams, Harry E. (1975). OEO and Political Activation: The Experience of Community Action Participants in Oakland and San Francisco. PhD Dissertation, Department of Political Science, University of California, Berkeley.

Wood, Jim (1968). In Spanish or in English, Poverty Problem Lives. Oakland Tribune, June 23, A8.

Zermeño, Alex (2011). Interview with the Author. August 2. 